\title{
Effect of Botanicals Seed Treatment for Seed Vigour of Maize Variety Vivek 27
}

\author{
Asha Sinha* and Shrvan Kumar \\ Mycology and Plant Pathology, IAS, Banaras Hindu University, \\ Varanasi-221 005, (U.P.), India \\ *Corresponding author
}

\begin{abstract}
A B S T R A C T
Keywords

Botanical extracts,

Maize,

Germination, Seed vigour index and Mycotoxins

Article Info

Accepted:

20 March 2019

Available Online:

10 April 2019

In this study the data pertaining to effect of five botanicals on Vivek 27 variety seed quality parameter of Vivek 27 variety revealed that seed treatment with Neem+ Tulsi, Neem+ Onion, Neem+ Garlic, Neem + Ginger were significantly superior over control. Neem extract seed treatment with combination other botanicals showed values range of per cent germination $91.00 \pm 3.83$ (Neem+ Ginger) to 98.00 \pm 3.21 (Neem+ Tulsi), fresh weight (g) $8.47 \pm 0.63(\mathrm{Neem}+\mathrm{Garlic})$ to $13.06 \pm 0.59$ (Neem+ Tulsi), dry weight (g) 2.52 \pm 0.16 $(\mathrm{Neem}+\mathrm{Garlic})$ to $3.70 \pm 0.15$ (Neem+ Tulsi), and seedling vigour index- dry weight 232.49 \pm 33.02 (Neem+ Ginger) to 358.95 \pm 15.45 (Neem+ Tulsi) at ratio 1:1, 2:1 and 1:2. However, Neem+Ginger ratio $(2: 1)$ and $(1: 2)$ minimum values of per cent germination $93 \pm 3.83$ and $91.00 \pm 3.83$, fresh weight $(\mathrm{g}) 8.78 \pm 1.86$ and $8.67 \pm 1.98$, dry weight $(\mathrm{g})$ $2.60 \pm 0.47$ and $2.57 \pm 0.50$ and seedling vigour index- dry weight $232.49 \pm 33.02$ and $232.49 \pm 53.50$, were showed. The botanical extracts are cheaper and eco-friendly practice for the control of seed-borne pathogens of maize.
\end{abstract}

\section{Introduction}

Maize (Zea mays ssp. mays L., 2n=20.) has worldwide significance as human food, animal feed and as raw material for the manufacture of hundreds of industrial products. Presently, maize is being used mainly for feed (63 per cent), food (23 per cent), starch industries (12 per cent) and seed and miscellaneous use ( 2 per cent) in India. It is estimated that by 2025 , India would require 50 MT maize grain, of which 32 MT would be required in the feed sector, $15 \mathrm{MT}$ in the industrial sector, $2 \mathrm{MT}$ as food, and $1 \mathrm{MT}$ for seed and miscellaneous purposes (Yadav et $a l$., 2016). Demand for food poses major challenges to humankind due to rising population. For facing these challenges humans used enormous amount of chemically synthesize fungicides because of their enormous use, easiness and extreme effectiveness to control plant diseases. Due to their harmful effects on human being as well as soil health, nowadays focus is shifting in the direction of biopesticides to manage plant diseases as they have no adverse consequence 
on humans as well as environment. Many factors may be responsible for mold growth, among them are adverse weather conditions, the high cost of mechanical drying, insect and rodent damage, and temperature differentials which cause moisture movement during storage and transport (Pitt, 1981). Mold growth in turn will cause loss of germinability, discoloration, loss of milling properties, rancidity from free fatty acid production, spoilage, and mycotoxin producdon. Fungal deterioration of stored grains is a chronic problem in the Indian storage system. When fungi associate with grains, they often reduce both the quality and yield of grains (Baliukoniene et al., 2003).

The active principles of the many drugs found in plants are secondary metabolites (Parekh et al., 2006). Medicinal plants are a source of great economic value all over the world. About three quarter of the world's population relies on plants and plant extracts for healthcare (Parekh and Chanda, 2008). Twelve thousand secondary metabolite have been isolated and the number estimazted to be less than 10 per cent of the total (Latha and Dubey, 2010; Sangvikar and Wadje, 2012). Different mechanisms of action of phytochemicals have been suggested. They may inhibit microorganisms, interfere with some metabolic processes or may modulate gene expression and signal transduction pathways (Kumar et al., 2017; Manson 2003; Surh 2003). The mechanism of action is considered to be the disturbance of the cytoplasmic membrane, disrupting the proton motive force, electron flow, active transport, and coagulation of cell contents (Kotzekidou et al., 2008). Plant extracts as control measures are cost effective and non-toxic methods. Plant based antifungal formulation are now being used (Uddin, 2013). In present investigation, Effect of various plant extracts on seed vigour of Maize variety Vivek 27 had been carried out.

\section{Materials and Methods}

\section{Screening of plant extracts}

\section{Preparation of plant extract}

Locally five plant extract were prepared by macerating leaves/ roots in ratios weight / volume $(1: 1)$ in distil sterilized water (DSW) and this extract is termed as standard extract (SE) (Table 1). Two hundred grams of fresh leaves from each plant were washed well and grinded in $200 \mathrm{ml}$ of DSW by using grinder. The macerate was filtered through double layered cheese cloth and centrifuged at 3500 rpm for 20 minutes. The supernatant was filtered through Whatmann No. 42 filter paper. The supernatant was putted into oven at $50{ }^{\circ} \mathrm{C}$ till half volume before used. This supernatant is pure stock $(100 \%)$.

Effect of seed treatments with botanicals on germination by multi-pot tray method (Khare, 1996)

The combination (Botanical: DSW) of botanicals1:1, 2:1 and 1:2 were made from standard extracts. Seed was dipped for 60 minutes and dried in shade before showing (Kumar, 2011 and Pandit, 2010). Each treatments were four replications $(25 \mathrm{X} 4=100$ Seeds). Different extracts were evaluated by multi-pot tray method (Khare, 1996).

\section{Standard Germination Test (\%)}

One hundred seeds with four replications of maize variety Vivek -27 was tested in the laboratory according to the Rules of International Seed Testing Association (ISTA, 2011). The final count of germination was recorded on 5th day and the number of normal seedlings was counted and expressed as per cent germination. 
$\mathrm{G}(\%)=\left[\mathrm{N}_{\mathrm{T}} \times 100\right] / \mathrm{N}$

Where,

$\mathrm{N}_{\mathrm{T}}$ : proportion of germinated seeds in each treatment for the final measurement

$\mathrm{N}$ : Number of seeds used in bioassay

\section{Seedling fresh weight $(\mathrm{g})$}

Normal germinating seedlings in four replications each of all the varieties were selected in separate paper bags and the seedling fresh weight was measured in gram and average seedling fresh weight was calculated.

\section{Seedling dry weight (g)}

For dry weight determination, all replication of seedlings are removed and dried in 2-3 days in air. These seedlings were placed in separate paper bags and then transferred into oven at $50^{\circ} \mathrm{C}$ for $8 \mathrm{~h}$ four times. The average weight of all replications of germination seedlings was taken and seedling dry weight was expressed in grams.

\section{Vigour index}

Seedling vigour index was calculated according to the formula suggested by AbdulBaki and Anderson (1973).

Vigour index=Standard germination (\%) $\mathrm{x}$ Seedling dry weight $(\mathrm{g})$

\section{Data analysis}

Data for seed health parameters were summarized and analysed using SAS ver. 9.1 (SAS Institute Inc., Cary, NC, USA) within the framework of general linear models.

The means were separated using LSD $(p=0.05)$ to determine whether there were significant differences among the among the seed quality parameter of Vivek 27 variety.

\section{Results and Discussion}

Data pertaining to effect of five botanicals on Vivek 27 variety seed are presented in Table 2 and Plate 1. Over all mean of all seed quality parameter of Vivek 27 variety revealed that seed treatment with Neem+ Tulsi, Neem+ Onion, Neem+ Garlic, Neem + Ginger were significantly superior over control. Among the four seed quality parameters viz., germination (GN), fresh weight (FW), dry weight (DW) and seedling vigour index- dry weight (SV) was recorded. In case of Neem extract seed treatment $(1: 1)$ with combination other botanicals showed values range of per cent germination $97.00 \pm 3.83$ (Neem+ Tulsi) to $92.00 \pm 3.26$ (Neem+ Ginger), fresh weight $(\mathrm{g}) 13.06 \pm 0.59$ (Neem+ Tulsi) to $9.72 \pm 0.76$ (Neem+ Onion), dry weight $(\mathrm{g}) 3.70 \pm 0.15$ (Neem+ Tulsi) to $3.17 \pm 0.16$ (Neem+ Garlic), and seedling vigour index- dry weight $358.95 \pm 15.45$ (Neem+ Tulsi) to 262.86 \pm 19.77 (Neem+ Ginger) and Neem+ Tulsi seed treatment(1:1) was achieved highest values of per cent germination-97.00 \pm 3.83 , fresh weight $(\mathrm{g})$ 13.06 \pm 0.59 , dry weight (g)-3.70 \pm 0.15 and seedling vigour index- dry weight 358.95 \pm 15.45 . Neem+Tulsi ratio $(2: 1)$ and (1:2) maximum values of per cent germination $98.00 \pm 2.31$ and $96.00 \pm 3.26$, fresh weight $(\mathrm{g}) 11.67 \pm 0.71$ and $8.70 \pm 1.16$, dry weight $(\mathrm{g}) 3.35 \pm 0.18$ and $2.58 \pm 0.30$ and seedling vigour index- dry weight $327.66 \pm 15.22$ and $247.36 \pm 26.11$, were showed.

Neem+Onion combination values of per cent germination 96.00 \pm 3.26 and 94.00 \pm 5.16 , fresh weight $(\mathrm{g}) 11.04 \pm 2.27$ and $10.16 \pm 1.68$, dry weight $(\mathrm{g}) 3.18 \pm 0.58$ and $2.96 \pm 0.43$ and seedling vigour index- dry weight $305.45 \pm 55.98$ and $279.06 \pm 53.36$ were obtained at ratio $(2: 1)$ and $(1: 2)$, respectively. Neem+Garlic seed treatment were achieved values of per cent germination $95.00 \pm 3.83$, fresh weight $(\mathrm{g}) 10.85 \pm 1.19$, dry weight $(\mathrm{g})$ 
$3.13 \pm 0.31$ and seedling vigour index- dry weight $297.05 \pm 21.65$ at ratio $2: 1$. At ratio $1: 2$ were showed values of per cent germination
93.00 \pm 5.03 , fresh weight $(\mathrm{g}) 8.47 \pm 0.63$, dry weight $(\mathrm{g}) 2.52 \pm 0.16$ and seedling vigour index- dry weight 234.24 \pm 9.46 .

Table.1 The particulars of botanicals used for seed treatment is given below

\begin{tabular}{|r|l|l|l|c|l|}
\hline $\begin{array}{l}\text { S. } \\
\text { No. }\end{array}$ & $\begin{array}{l}\text { Common } \\
\text { /English name }\end{array}$ & $\begin{array}{l}\text { Botanical } \\
\text { Name }\end{array}$ & Family & $\begin{array}{l}\text { Plant parts } \\
\text { used }\end{array}$ & \multicolumn{1}{|c|}{ Active substance } \\
\hline 1. & $\begin{array}{l}\text { Neem/ Indian- } \\
\text { lilac/ Margosa } \\
\text { (India) }\end{array}$ & $\begin{array}{l}\text { Azadirachta } \\
\text { indica A. Juss }\end{array}$ & Meliaceae & Leaves & $\begin{array}{l}\text { Azadirachtin: Limonoids/ } \\
\text { tetranortriterpenes } \\
\text { (Roy and Saraf, 2006) }\end{array}$ \\
\hline 2. & $\begin{array}{l}\text { Tulsi/Basil } \\
\text { (India) }\end{array}$ & $\begin{array}{l}\text { Ocimum } \\
\text { sanctum L. }\end{array}$ & Lamiaceae & Leaves & $\begin{array}{l}\text { Ocimene, camphor, g- } \\
\text { terpineol, methyl cinnamate } \\
\text { (Hussain } \text { et al., 2008) }\end{array}$ \\
\hline 3. & $\begin{array}{l}\text { Onion/ Payaj } \\
\text { (Central Asia) }\end{array}$ & Alliumcepa L. & Amaryllidaceae & Bulbs & $\begin{array}{l}\text { Quercetin, Dimethyl trisulfide } \\
\text { (Marrelli } \text { et al., 2019) }\end{array}$ \\
\hline 4. & $\begin{array}{l}\text { Garlic/ Lahsun } \\
\text { (Central Asia) }\end{array}$ & $\begin{array}{l}\text { Allium } \\
\text { sativum L. }\end{array}$ & Amaryllidaceae & Cloves & $\begin{array}{l}\text { Diallyl disulfide, Diallyl } \\
\text { trisulfide, allyl } \\
\text { disulfide (Hussein et al., }\end{array}$ \\
\hline 5. & $\begin{array}{l}\text { Ginger/ Adrakh } \\
\text { (South-East Asia) }\end{array}$ & $\begin{array}{l}\text { Zingiber } \\
\text { officinale Rosc. }\end{array}$ & Zingiberaceae & Rhizomes & $\begin{array}{l}\text { Gingerol, } \\
\text { (Mohamedin } \text { et al., 2018) }\end{array}$ \\
\hline
\end{tabular}

Table.2 Effect of botanicals on maize variety Vivek 27 seed dressing through multipots tray method

\begin{tabular}{|c|c|c|c|c|c|}
\hline \hline Treatments & $\begin{array}{c}\text { Concentration } \\
\text { Ratio }\end{array}$ & $\begin{array}{c}\text { Germination } \\
\text { (in \%) }\end{array}$ & $\begin{array}{c}\text { Fresh Weight } \\
\text { (in gm) }\end{array}$ & $\begin{array}{c}\text { Dry Weight } \\
\text { (in gm) }\end{array}$ & $\begin{array}{c}\text { Seedling } \\
\text { Vigour index }\end{array}$ \\
\hline Neem+ Tulsi & $1: 1$ & $97.00 \pm 3.83 \mathrm{a}$ & $13.06 \pm 0.59 \mathrm{a}$ & $3.70 \pm 0.15 \mathrm{a}$ & $358.95 \pm 15.45 \mathrm{a}$ \\
\hline & $2: 1$ & $98.00 \pm 2.31 \mathrm{a}$ & $11.67 \pm 0.71 \mathrm{a}$ & $3.35 \pm 0.18 \mathrm{a}$ & $327.66 \pm 15.22 \mathrm{a}$ \\
\hline Neem+Onion & $1: 2$ & $96.00 \pm 3.26 \mathrm{a}$ & $8.70 \pm 1.16 \mathrm{~b}$ & $2.58 \pm 0.30 \mathrm{~b}$ & $247.36 \pm 26.11 \mathrm{~b}$ \\
\hline & $1: 1$ & $95.00 \pm 3.82 \mathrm{ab}$ & $9.72 \pm 0.76 \mathrm{~b}$ & $2.85 \pm 0.19 \mathrm{ab}$ & $269.88 \pm 17.51 \mathrm{~b}$ \\
\hline & $2: 1$ & $96.00 \pm 3.26 \mathrm{a}$ & $11.04 \pm 2.27 \mathrm{a}$ & $3.18 \pm 0.58 \mathrm{a}$ & $305.45 \pm 55.98 \mathrm{a}$ \\
\hline Neem+Garlic & $1: 2$ & $94.00 \pm 5.16 \mathrm{ab}$ & $10.16 \pm 1.68 \mathrm{ab}$ & $2.96 \pm 0.43 \mathrm{ab}$ & $279.06 \pm 53.36 \mathrm{a}$ \\
\hline & $1: 1$ & $94.00 \pm 4.00 \mathrm{ab}$ & $10.97 \pm 0.63 \mathrm{ab}$ & $3.17 \pm 0.16 \mathrm{a}$ & $297.19 \pm 5.93 \mathrm{a}$ \\
\hline & $2: 1$ & $95.00 \pm 3.83 \mathrm{ab}$ & $10.85 \pm 1.19 \mathrm{ab}$ & $3.13 \pm 0.31 \mathrm{a}$ & $297.05 \pm 21.65 \mathrm{a}$ \\
\hline Neem+Ginger & $1: 2$ & $93.00 \pm 5.03 \mathrm{ab}$ & $8.47 \pm 0.63 \mathrm{~b}$ & $2.52 \pm 0.16 \mathrm{~b}$ & $234.24 \pm 9.46 \mathrm{~b}$ \\
\hline & $1: 1$ & $92.00 \pm 3.26 \mathrm{ab}$ & $10.03 \pm 0.57 \mathrm{ab}$ & $2.92 \pm 0.14 \mathrm{ab}$ & $262.86 \pm 19.77 \mathrm{~b}$ \\
\hline & $2: 1$ & $93 \pm 3.83 \mathrm{ab}$ & $8.78 \pm 1.86 \mathrm{c}$ & $2.60 \pm 0.47 \mathrm{~b}$ & $232.49 \pm 33.02 \mathrm{c}$ \\
\hline Control & $1: 2$ & $91.00 \pm 3.83 \mathrm{~b}$ & $8.67 \pm 1.98 \mathrm{~b}$ & $2.57 \pm 0.50 \mathrm{~b}$ & $232.49 \pm 53.50 \mathrm{~b}$ \\
\hline MSD (P= 0.05) & & $90.00 \pm 6.93 \mathrm{~b}$ & $8.52 \pm 0.59 \mathrm{c}$ & $2.53 \pm 0.15 \mathrm{c}$ & $232.86 \pm 7.58 \mathrm{~b}$ \\
\hline EMS & & $\mathbf{5 . 3 9 1 2}$ & $\mathbf{1 . 4 7 1 1}$ & $\mathbf{0 . 3 7 7 6}$ & $\mathbf{3 6 . 1 4 4 0}$ \\
\hline & & $\mathbf{2 1 . 4 7 3 0}$ & $\mathbf{1 . 5 9 8 8}$ & $\mathbf{0 . 1 0 5 4}$ & $\mathbf{9 6 5 . 1 5 7 6}$ \\
\hline
\end{tabular}


Plate.1
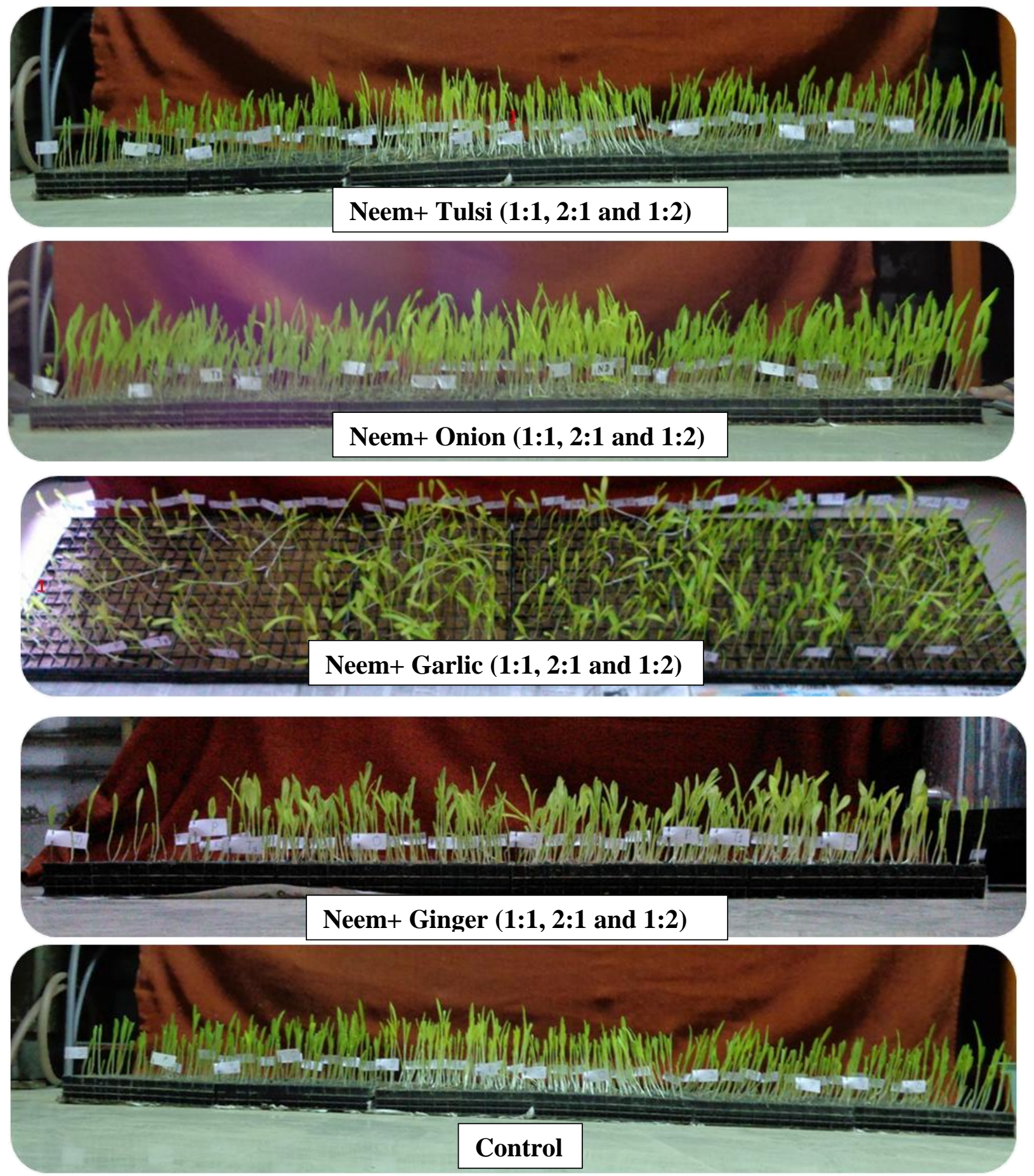

- Plate 1: Neem and other botanicals combination

Interaction effect between different concentration ratio and botanicals treatments showed significant difference with respect to control at level $\mathrm{P}=0.05$. Neem+Ginger ratio
(2:1) and (1:2) minimum values of per cent germination $93 \pm 3.83$ and $91.00 \pm 3.83$, fresh weight (g) $8.78 \pm 1.86$ and $8.67 \pm 1.98$, dry weight (g) $2.60 \pm 0.47$ and $2.57 \pm 0.50$ and 
seedling vigour index- dry weight $232.49 \pm 33.02$ and $232.49 \pm 53.50$, were showed.

There is no report on effect of botanicals seed treatment for seed vigour of Maize in literature. So, seed invigouration done midway during storage has been reported to improve the seed viability and vigour during subsequent storage. The chemically treated seeds generally store better in storage and show better field performance (Pegah et al., 2008).

In conclusion, in the present findings, Neem+ Tulsi seed treatment (1:1) was achieved highest values of per cent germination$97.00 \pm 3.83$, fresh weight $(\mathrm{g})-13.06 \pm 0.59$, dry weight $(\mathrm{g})-3.70 \pm 0.15$ and seedling vigour index- dry weight $358.95 \pm 15.45$. Therefore, botanical extracts are cheaper and ecofriendly practice for the seed-borne diseases of maize. This may provide a better management of the seed-borne diseases.

\section{Acknowledgement}

Research was funded by Uttar Pradesh Council of Science and Technology for "Development of Eco-friendly formulation of phyto-extracts against seed borne pathogens of Zea mays L".

\section{References}

Abdul, B. A.A. and Anderson, J.D., Vigour determination in soybean seed by multiple criteria. Crop Science, 73, 630-633, 1973.

Baliukoniene, V., Bakutis, B., and Stankevicius, H. (2003). Mycological and mycotoxicological evaluation of grain. Annals of Agricultural and Environmental Medicine, 10(2), 223227.

Hussain, A. I., Anwar, F., Sherazi, S. T. H., and Przybylski, R. (2008). Chemical composition, antioxidant and antimicrobial activities of basil (Ocimum basilicum) essential oils depends on seasonal variations. Food chemistry, 108(3), 986-995.

Hussein, H. J., Hameed, I. H., and Hadi, M. Y. (2017). A Review: Anti-microbial, Anti-inflammatory effect and Cardiovascular effects of Garlic: Allium sativum. Research Journal of Pharmacy and Technology, 10(11), 4069-4078.

ISTA, Seed Testing International, ISTA News Bulletin No.142, 1-60, 2011,

Khare, M.N., Methods to test seeds for associated fungi. Indian Phytopathology, 49, 323-323, 1996.

Kotzekidou, P.; Giannakidis, P., Boulamatsis, A. (2008). Antimicrobial activity of some plant extracts and essential oils against foodborne pathogens in vitro and on the fate of inoculated pathogens in chocolate. LWT, 41: 119-127.

Kumar S. 2011. Studies on management of Karnal bunt of wheat. M.Sc. Thesis, Department of Plant Pathology, CSK Himachal Pradesh Krishi Vishvavidyalaya, Palampur, India. p.32.

Kumar S., Sinha A. and Singh S., Ecological Biodiversity Measurement of Seed Mycoflora Contamination of Freshly Harvested in Maize Growing Zone-II. Journal of Pure and Applied Microbiology, 11(1), 479-486, 2017. doi: http://dx.doi.org/10.22207/JPAM. 11.1.63

Latha N. and Dubey V. 2010. Quantification and identification of alkaloids of Eichornia crassipes: the world's worst aquatic plant. J. Pharmecy Res., 3(6): 1229-1231.

Manson, M.M. (2003). Cancer prevention the potential for diet to modulate molecular signalling. Trends in Molecular Medicine. 9: 11-18.

Marrelli, M., Amodeo, V., Statti, G., and 
Conforti, F. (2019). Biological Properties and Bioactive Components of Allium cepa L.: Focus on Potential Benefits in the Treatment of Obesity and Related Comorbidities. Molecules, 24(1), 119.

Mohamedin, A., Elsayed, A., and Shakurfow, F. A. (2018). Molecular Effects and Antibacterial Activities of Ginger Extracts against Some Drug Resistant Pathogenic Bacteria. Egyptian Journal of Botany, 58(1), 133-143.

Pandit D. 2010.Epidemiology and management of anthracnose of horse gram (Macrotyloma uniflorum) M.Sc. Thesis, Department of Plant Pathology, CSK Himachal Pradesh Krishi Vishvavidyalaya, Palampur, India. p19.

Parekh, J., and Chanda, S. (2008). Phytochemical screening of some plants from western region of India. Plant Archives, 8(2), 657-662.

Parekh, J., Jadeja, D., and Chanda, S. (2006). Efficacy of aqueous and methanol extracts of some medicinal plants for potential antibacterial activity. Turkish Journal of Biology, 29(4), 203-210.

Pegah, M. D., Sharif Zadeh, F. and Janmohammadi. M., (2008), Influence of priming techniques on seed germination behaviour of maize inbred lines (Zea mays L.). ARPN Journal of Agricultural and Biological Sciences. 3(3): 22-25.

Pitt J.I. 1981. Food Spoilage and Biodeterioration In: Biology of Conidial Fungi Vol.-2 editor Garry T. Cole and
Bryce Kendrick, Academic Press New York. pp. 111-137.

Roy, A. and Saraf, S., Limonoids: Overview of Significant Bioactive Triterpenes Distributed in Plants Kingdom". Biological and Pharmalogical Bulletin, 29(2), 191-201, 2006.

Sangvikar V. R. and Wadje S.S., In-vivo Testing of Plant Extracts against Seed borne Pathogens. International Research Journal of Biological Sciences, 1(6), 14, 2012.

Sinha A., Singh S., Kumar S. and Rai S. 2018. In vitro Antifungal Potencyof Plant Extracts against Post-Harvest Storage Fungal Pathogens of Zea mays L.Int.J.Curr.Microbiol.App.Sci. 7(04): 1236-1247. doi: https://doi.org/10. 20546/ijcmas.2018.704.138

Surh, Y.J. (2003). Cancer chemoprevention with dietary phytochemicals. Natural Reviews in Cancer. 3: 768-780.

Uddin, S. B., Sultana, F. O., and Faruque, O. (2013). Antibacterial activity of some selected medicinalplants used by the Rakhaing Community of Cox ${ }^{\text {ee }} \mathrm{s}$ Bazar district Bangladesh. Academia Journal of Microbiology Research, 2(1), 021027.

Yadav O.P., Prasanna B.M., Yadava P., Jat S.L., Kumar D., Dhillon B.S., Solanki I. S. and Sandhu J. S., Doubling maize (Zea mays) production of India by 2025 - Challenges and opportunities. Indian Journal of Agricultural Sciences 86 (4): 427-34, 2016.

\section{How to cite this article:}

Asha Sinha and Shrvan Kumar. 2019. Effect of Botanicals Seed Treatment for Seed Vigour of Maize Variety Vivek 27. Int.J.Curr.Microbiol.App.Sci. 8(04): 2742-2748. doi: https://doi.org/10.20546/ijcmas.2019.804.319 